\section{The effects of response-contingent and noncontingent shock on free operant avoidance}

\author{
ROBERT T. JONES, University of Exeter, \\ Exeter, England 00260
}

The effect of noncontingent shock and the same rate of $F I$ and $F R$ schedules of response-contingent shock deliveries on a baseline of nondiscriminated operant avoidance was studied. Four rats received each of the conditions. The number of unavoided shocks decreased in the order FR, baseline, FI, noncontingent shock. For three Ss the response rate increased in the same order, but for the other $S$ the positions of the baseline and $F I$ conditions were

Recently there have been a number of investigations of the effects of additional shocks superimposed on a schedule of free operant avoidance. The initial findings of Sidman, Herrnstein, \& Conrad (1957) that response rate increases when noncontingent shocks are added to an avoidance schedule have been confirmed several times, e.g., Kelleher, Riddle, \& Cook (1963), and McIntire, Davis, Cohen, \& French (1968). The superimposition of response-contingent shock has led to a decrease in response rate when every response was punished (Powell \& Morris, 1969) and when additional shocks were programmed on fixed-ratio (FR) schedules (Sandler, Davidson, \& Holzschuh, 1966; McIntire et al, 1968), but to an increase in responding when programmed on fixed-interval (FI) schedules (McKearney, 1969).

All the investigations showing an increase in responding using response-contingent shock have used monkeys as Ss. It is therefore possible that this effect is limited to this type of species, especially as the effect is not limited to situations using an avoidance baseline. Kelleher \& Morse (1968) have shown that an FI schedule of response-contingent shock increases responding on a VI schedule of food presentation, and Morse, Mead, \& Kelleher (1967) showed that noncontingent shocks, which originally elicited responses, could later be used to reinforce responding when there was no other schedule of reinforcement in operation and shocks were made response-contingent. Both of these experiments used squirrel monkeys as Ss.

Kelleher \& Morse (1968) also found that shock led to a decrease in baseline responding. This may have been due to the reversed. an FR schedule of response-contingent higher shock rate prevailing in this component of the schedule: high shock rate may lead to a decrease in responding but low shock rate to an increase. Using rats, McIntire et al (1968) found that a FR schedule of response-contingent shock led to a decrease in responding of an avoidance baseline whereas the same rate of noncontingent shock increased responding.

This investigation studied the effect of the same rate of noncontingent shock; and FI and FR schedules of response-contingent shock on an operant avoidance baseline in rats.

\section{SUBJECTS}

The Ss were four male hooded rats, 4 months old at the siart of the experiment. APPARATUS

Two Lehigh Valley operant conditioning boxes, Nos. 1316 and 1417, were used. Each was enclosed in a sound-resistant cubicle, Lehigh Valley Models $1316 \mathrm{C}$ and $1417 \mathrm{C}$, respectively. Only the right-hand lever was present in each box. Illumination was provided by a 7-W houselight.

The floor of each box consisted of 16 steel rods through which foot shock from a Behaviour Apparatus constant power shock scrambler was delivered at a set $0.8 \mathrm{~mA}$. The duration of each shock was 0.34 sec and this and other experimental contingencies were controlled by relays and circuitry in an adjacent room.

\section{PROCEDURE}

The experiment was conducted in four stages. At each stage performance was allowed to stabilize; the criterion of stability was that none of the response rates of the last four sessions should differ from the mean of these sessions by more than $5 \%$.
The Ss were first put on a schedule of nondiscriminated free-operant avoidance (Sidman, 1953) with shock-shock interval = $5 \mathrm{sec}$ and response-shock interval $=30 \mathrm{sec}$. This baseline schedule remained unaltered throughout the experiment. Deliveries of noncontingent shocks were then overlaid on the basic schedule every $5 \mathrm{~min}$. These shocks were next made response-contingent. In the fourth stage, a FR schedule of response-contingent shock was introduced. This was adjusted for each $S$ until the rate of presentation of response-contingent shock was the same as in the second and third stages, i.e., 24 per session.

Sessions, which were run every day, were $3 \mathrm{~h}$ in length and data were only collected from the final $2 \mathrm{~h}$.

\section{RESULTS}

The number of responses in each stage of the experiment for each $S$ are shown in Table 1. Three Ss gave an identical pattern of results. The FR schedule of response-contingent shock led to a decrease in responses when compared with the basic avoidance schedule. Both the FI schedule of response-contingent shock and the noncontingent shock presentations led to increases in responding, the latter giving the greater increase. The responding of the other $\mathrm{S}$ (No. 542) was decreased by both types of response-contingent shock, the FR schedule giving the greater decrease. Noncontingent shock again led to an increase over the baseline response rate. The conditions had a differential effect on response rate (Friedman two-way analysis of variance, $\chi^{2}=11.1, p=0.00094$ ).

The pattern of the data on unavoided shocks due to the avoidance schedule was the same for all Ss. Most shocks were received under the FR schedule with progressively less being received under the baseline, FI, and noncontingent conditions. The conditions had a differential effect on shock rate (Friedman two-way analysis of variance, $\chi^{2}=12.0, p=0.000072$ )
Table 1

Mean Number of Responses, Unavoided Shocks, and the Associated Efficiency Index for Each Rat Under Each Experimental Condition

\begin{tabular}{|c|c|c|c|c|c|}
\hline \multirow[b]{2}{*}{$\mathbf{S}$} & \multirow[b]{2}{*}{ Measure } & \multirow{2}{*}{$\begin{array}{c}\text { Avoidance } \\
\text { Baseline }\end{array}$} & \multicolumn{3}{|c|}{ Additional Shock Schedule } \\
\hline & & & $\mathbf{F R}$ & FI & Noncontingent \\
\hline 541 & $\begin{array}{l}\text { Responses } \\
\text { Unavoided Shocks } \\
\text { Efficiency Index }\end{array}$ & $\begin{array}{r}1158 \\
11 \\
.045\end{array}$ & $\begin{array}{r}1068 \\
33 \\
.13\end{array}$ & $\begin{array}{r}1891 \\
5 \\
.031\end{array}$ & $\begin{array}{r}2295 \\
4 \\
.029\end{array}$ \\
\hline 542 & $\begin{array}{l}\text { Responses } \\
\text { Unavoided Shocks } \\
\text { Efficiency Index }\end{array}$ & $\begin{array}{r}644 \\
148 \\
.38\end{array}$ & $\begin{array}{r}604 \\
150 \\
.37\end{array}$ & $\begin{array}{r}614 \\
132 \\
.33\end{array}$ & $\begin{array}{r}647 \\
118 \\
.30\end{array}$ \\
\hline 546 & $\begin{array}{l}\text { Responses } \\
\text { Unavoided Shocks } \\
\text { Efficiency Index }\end{array}$ & $\begin{array}{r}558 \\
224 \\
.52\end{array}$ & $\begin{array}{r}532 \\
228 \\
.51\end{array}$ & $\begin{array}{r}615 \\
205 \\
.51\end{array}$ & $\begin{array}{r}635 \\
203 \\
.52\end{array}$ \\
\hline 544 & $\begin{array}{l}\text { Responses } \\
\text { Unavoided Shocks } \\
\text { Efficiency Index }\end{array}$ & $\begin{array}{r}1070 \\
22 \\
.084\end{array}$ & $\begin{array}{r}977 \\
44 \\
.16\end{array}$ & $\begin{array}{r}1128 \\
16 \\
.064\end{array}$ & $\begin{array}{r}1258 \\
14 \\
.061\end{array}$ \\
\hline
\end{tabular}


McIntire et al (1968) described an index of the efficiency of responding under a free operant avoidance schedule as: (Number of shocks received/Maximum possible shocks) $X$. [(Total responses + Minimum responses for total avoidance)/Minimum responses for total avoidance]. Values of this index for each $S$ under all conditions are also shown in Table 1. There was no differential effect on this variable, however (Friedman two-way analysis of variance, $\chi^{2}=7.5, p=0.052$ ). This was largely due to the results of $S 546$, who gave virtually no change in the index between conditions.

\section{DISCUSSION}

In three of the four rats, response-contingent shocks on a FI schedule, in addition to those programmed on the avoidance baseline, led to an increase in responding. It thus seems that this effect is not limited to the various species of monkeys. The usual effect of noncontingent shock in increasing response rate was again confirmed, and noncontingent shock increased responding more than a FI schedule of response-contingent shock at the same shock rate.

Again in three cases, a FR schedule of response-contingent shock led to a decrease in responding whereas a similar FI schedule at the same rate of shock presentation and in the same $S$ led to an increase. This indicates that, although the rate of presentation of response-contingent shock may determine whether an increase or a decrease in responding occurs (Kelleher \& Morse, 1968), the schedule of shock presentation, itself, is an important factor.

This investigation confirmed the main findings of McIntire et al (1968). There were two differences, however. First, the Ss in this experiment were generally more efficient in responding to avoid shocks as measured by their efficiency index. McIntire et al (1968) also found that the efficiency index showed responding under noncontingent additional shocks to be more efficient and responding under FR response-contingent shocks to be less efficient than the baseline responding. Here, although the results for the noncontingent shock procedure were confirmed, two Ss showed less efficient responding under the FR condition, but the other two gave slight increases in efficiency. The present results seem to lie between those of McIntire et al (1968) and those of Sandler et al (1966). The latter, when using marmoset monkeys in a similar situation, were able to report that their Ss established "... an optimal balance ... between adequate avoidance responding and minimal exposure to punishment contingencies."

Which response-contingent shock procedures are defined as punishment procedures depends on the definition of punishment that is adopted. If a functional definition is accepted, e.g., ". . . punishment is a reduction of the future probability of a specific response as a result of the immediate delivery of a stimulus for that response [Azrin \& Holz, 1966,p. 381]," then the FR shock schedules, and in one case (S 542) the FI schedule, were punishment procedures. Any possible punishing effect of the FI schedule in the other cases was masked by more powerful variables. If a definition based on the concept of a reinforcer is accepted, e.g., ". . . withdrawing a positive reinforcer or presenting a negative ... appear to constitute the field of punishment [Skinner, 1953, p. 185]," then all the response-contingent shock procedures are punishment procedures. In this case, three of the eight punishment procedures (the FI schedules of shock presentation for Ss 541 , 546, and 544) demonstrate "paradoxical" effects or the ineffectiveness of punishment.

\section{REFERENCES}

AZRIN, N. H., \& HOLZ, W. C. Punishment. In W. K. Honig (Ed.), Operant behavior: Areas of research and application. New York: Appleton-Century-Crofts, 1966. Pp. 380-447. KELLEHER, R. T., \& MORSE, W. H. Schedules using noxious stimuli. III. Responding maintained with response-produced electric shock. Journal of the Experimental Analysis of Behavior, 1968, 11, 819-838.
KELLEHER, R. T., RIDDLE, W. C., \& COOK, L. Persistent behavior maintained by unavoidable shocks. Joumal of the Experimental Analysis of Behavior, 1963, 6, 507-517.

MCINTIRE, R. W., DAVIS, H., COHEN, S. I., \& FRANCH, E.O.Sidman avoidance performance under punishment and non-contingent shock conditions. Psychological Reports, 1968, 22 897.903.

McKEARNEY, J. W. Fixed-interval schedules of electric shock presentation: Extinction and recovery of performance under different shock intensities and fixed-interval durations. Joumal of the Experimental Analysis of Behavior, 1969, 12,301-313.

MORSE, W. H., MEAD, R. N., \& KELLEHER, R. T. Modulation of elicited behavior by a fixed-interval schedule of electric shock presentation. Science, 1967, 157, 215-217.

POWELL, R. W., \& MORRIS, G. Continuous punishment of free operant avoidance in the rat. Journal of the Experimental Analysis of Behavior, 1969, 12,149-157.

SANDLER, J., DAVIDSON, R. S., \& HOLZSCHUH, R. D. Effects of increasing punishment frequency on Sidman avoidance behavior. Psychonomic Science, 1966, 5, 103-104.

SIDMAN, M. Two temporal parameters of the maintenance of avoidance behavior by the white rat. Journal of Comparative \& Physiological Psychology, 1953, 46, 253-261.

SIDMAN, M., HERRNSTEIN, R. J., \& CONRAD, D. G. Maintenance of avoidance behavior by unavoidable shocks. Journal of Comparative \& Physiological Psychology, 1957, 50, 553-557. SXINNER, B. F. Science and human behavior. New York: Macmillan, 1953.

\section{A further analysis of conjunctive reinforcement schedules ${ }^{1}$}

\section{E. WADE HITZING and JAMES H. KAYE, Kalamazoo State Hospital, Kalamazoo, Mich. 49001}

Pigeons were first tested on a fixed-interval 3-min reinforcement schedule. The simple fixed interval was then changed to a conjunctive schedule by the addition of a fixed-ratio requirement. On the conjunctive schedule, responding was reinforced only after at least 3 min had elapsed and after the emission of some minimum number of responses. The two initial ratio requirements programmed produced an increase in response rate, but a third addition to the response requirement resulted in a total cessation of responding.

In a conjunctive (conj) fixed-interval (FI), fixed-ratio (FR) schedule, responding is reinforced only after the passage of a fixed time period and the emission of some minimal number of responses. Previous research by Herrnstein \& Morse (1958) has shown that a conj FI FR schedule maintains a lower rate of responding than a simple FI of the same duration. It has not yet been 